\title{
THE USE OF MOBILE APPLICATION ACCEPTANCE MODEL IN MOBILE BANKING*
}

\author{
DOI: 10.17261/Pressacademia.2021.1466 \\ RJBM- V.8-ISS.4-2021(3)-p.243-259 \\ Esra Gursel ${ }^{1}$, Mustafa Yanartas ${ }^{2 * *}$ \\ ${ }^{1}$ Duzce University, Management Information Systems, Duzce, Turkey. \\ esragursel@yahoo.com, ORCID: 0000-0003-3347-6112 \\ ${ }^{2}$ Duzce University, Management Information Systems, Duzce, Turkey. \\ mustafayanartas@duzce.edu.tr, ORCID: 0000-0003-2063-103X
}

\begin{tabular}{l}
\hline Date Received: June 22, $2021 \quad$ Date Accepted: October 10, 2021 OPEN OACCESS (cc) BY \\
\hline To cite this document \\
Gursel, E., Yanartas, M., (2021). The use of mobile application acceptance model in mobile banking. Research Journal of Business and Management \\
(RJBM), 8(4), 243-259. \\
Permanent link to this document: http://doi.org/10.17261/Pressacademia.2021.1466 \\
Copyright: Published by PressAcademia and limited licesced re-use rights only.
\end{tabular}

\section{ABSTRACT}

Purpose- Mobile banking can reveal the behavioral intention for the acceptance and adoption of mobile banking by bank customers with the mobile application acceptance model.

Methodology- The quantitative research method was used and the data were obtained by using face-to-face interview survey technique and online survey application over the internet. The questionnaire was used as a data collection tool. Survey participants were reached with the convenience sampling method. The related 5-point Likert Type scale was used to measure the variables of the research. ${ }^{1}$

Findings- The demographic information of the participants, the findings of the exploratory and confirmatory factor analysis related to the scale used, and the analyzes related to the hypothesis testing were made. In this research, the data were analyzed by applying the structural equation model (SEM) with the LISREL program. And also descriptive analyzes and factor analyses were performed with IBM SPSS Statistics 23.

Conclusion- It has been determined that there is a significant and positive relationship between needs and perceived usefulness, perceived usefulness and attitude towards use, performance expectation and perceived benefit, needs and performance expectation, attitude towards use, and behavioral intention demonstrate a positive and significative relevance between each other. Moreover, it was observed that subjective norms had a positive effect on the attitude towards use, however, it was also diagnosed that it remained relatively low compared to the effect of other variables.

Keywords: Mobile banking, mobile application acceptance model, management information systems, structural equation model JEL Codes: 3 JELL O16, O33, L86

\section{MOBIL UYGULAMA KABUL MODELI’NIN MOBIL BANKACILIKTA KULLANILMASI}

\section{ÖZET}

Amaç- Mobil bankacılığın, banka muşterileri tarafından kabul edilmesine ve benimsenmesine yonelik davranışsal niyetini, mobil uygulama kabul modeli ile ortaya koymaktır.

Yöntem- Çalışmada, nicel araştırma yöntemi kullanılmış ve veriler yüz yüze görüşme anket tekniği ile internet üzerinden çevrimiçi anket uygulamasından yararlanılarak elde edilmiştir. Veri toplama aracı olarak anket kullanılmıştır. Kolayda örneklem metoduyla anket katılımcılarına ulaşılmıştır. Araştırmanın değişkenlerini ölçmek için ilişkin 5’li Likert Tipi ölçek kullanılmıştır.

Bulgular- Katılımcılara ait demografik bilgiler, kullanılan olceğe ilişkin acımlayıcı ve doğrulayıı faktor analizi bulguları ile hipotez testine ilişkin analizler yapılmıştır. Araştırmada LISREL programı ile yapısal eşitlik modeli(YEM) uygulanarak veriler analiz edilmiştir. Ayrıca IBM SPSS Statistics 23 ile betimleyici analizler ve faktör analizi yapılmıştır.

Sonuç- Gereksinimler ile algılanan fayda, algılanan fayda ile kullanıma yönelik tutum, performans beklentisi ile algılanan fayda, gereksinimler ile performans beklentisi, kullanıma yönelik tutum ile davranışsal niyet arasında anlamlı düzeyde ve pozitif yönlü bir ilişkinin varlı̆̆ı tespit edilmiştir. Öznel normların kullanıma yönelik tutum üzerinde pozitif yönde etkiye sahip olduğu görülmüş, ancak diğer değişkenlerin etkisine göre nispeten düşük kaldığı da tespit edilmiştir.

Anahtar Kelimeler: Mobil bankacılık, mobil uygulama kabul modeli, yönetim bilişim sistemleri, yapısal eşitlik modeli JEL Kodları: 3 JELL O16, O33, L86

"This article is adapted from the master's thesis titled "Using the Mobile Application Acceptance Model in Mobile Banking".

${ }^{* *}$ Corresponding autor 


\section{GíRiş}

Dijital bankacılığa adaptasyon sürecinde bilgi teknolojisinde yaşanan gelişmeler, bankacılık sektöründe rekabetçi bir pazarlama ortamını oluşturdu. Müşteri odaklı bir bankacılık anlayışının yerleşmesiyle bankalar hız, zaman ve maliyet avantajının yüksek olduğu uygulamalara yöneldiler. İternet ve mobil bankacılığı daha verimli kullanma, bankacılık ürünlerini çeşitlendirme faaliyetlerine yoğunlaşarak çok daha geniş kullanıcı kitlelerine hizmet vermeyi amaçlamıştır.

Bankalar finansal teknolojilere çok ciddi yatırım yaptılar. Büyük gayretlerle gelişen ve değişen teknolojileri sunulan hizmetler için kullanmaya çalışmaktadırlar. Böylelikle daha etkin ve verimli hizmetler sunmak hedeflenmektedir. Ancak verilen hizmetlerin doğası gereği birçok sıkıntı da beraberinde gelmektedir. Bu sıkıntıların en önemlileri bankaların kullandığı teknolojileri sorgulanmasına ve müşterilerin finansal teknolojilerle sunulan hizmetleri kullanma isteğini olumsuz etkilemesidir. Hâlbuki bankalar sundukları hizmetlerin müşterileri tarafından kullanılma seviyelerinin yüksek olmasını isterler. Bu noktada Teknoloji kabul kavramı gündeme gelmektedir. Çünkü sunulan hizmetin müşteri tarafından kullanma isteğinin oluşması ile hizmetin kalitesi ve içeriği arasında ciddi bir ilişki vardır (Güven ve Öztürk, 2014:127).

Dolayısıyla finansal teknolojilerin üretilmesi ve müşteri kullanımı arasındaki paralellik, finansal hizmetlerin amacına ulaşmasında etkilidir. Bu nedenle müşteri memnuniyetini en üst seviyede tutmayı hedefleyen bankalar, finansal teknoloji uygulamalarını yakından takip ederek işlem hızı, zaman ve maliyet açısından rekabet avantajları sağlamaya başlamıştır. Bankacılık sektörü, müşteri memnuniyeti ve kar maksimizasyonu amaçlarını gerçekleştirmek için yeni finansal ürünlerin piyasalarda kabul görmesine, yaygınlaşmasına ve genele yayılmasında doğrudan katkısı bulunan yeni teknolojilerden yararlanma yoluna gitmiş ve bunun sonucunda, dijital bankacılık kavramı ortaya çıkmıştır.

Dijital bankacılık uygulamalarının müşteriler tarafından kabul edilmesi, kullanılması ve hizmet noktası olarak tercih edilmesine ilişkin teknolojinin kabulüne yönelik algısal ve tutumsal çalışmalar yapılmış ve modeller ileri sürülmüştür. Bu modeller birbirleri ile çelişmemekle birlikte farklı açılardan yaklaşımlarla kendi analizlerine göre değerlendirmeler yapmaktadırlar.

Teknoloji kabulünü ve kullanımı üzerinde yapılan araştırmalar sonucu elde edilen teoriler/modeler, asıl itibariyle psikolojideki davranışsal teorileri temel almaktadır. Davranışsal teoriler davranışların oluşumundaki motivasyonları, inançları, algıları inceler. Pazarlama alanında müşterilerin davranışlarını anlama çabalarında bu teoriler kullanılır. Böylelikle müşterilerin bir ürünü satın alması, kullanması ve tekrar satın alması davranışlarının anlaşılması işletmeler açısından oldukça değerli bilgilerdir. (Türker, 2019:3-4)

Müşteri isteklerini önemseyen işletmeler, müşteri isteklerini karşılayacak ürün ve hizmetlerini en uygun şekilde müşterileri ile buluşturmayı amaçlarlar. Müşteri isteklerinin, taleplerinin ve eğilimlerinin çözümlenmesi ile doğru yeni ürün ve hizmetlerin üretilmesi sağlanacaktır. Yeni ürün veya hizmetlerin müşteriler tarafından kullanımında, ürün ve hizmet verimliliğini artırmak için, çoğu zaman yeni teknolojiler karşılaşılmaktadır. Yeni teknolojiler ise müşteri tarafında zaman zaman sıkıntılar oluşturmaktadır. Bu durumda işletmelerin müşteri davranışlarını öngörülebilmesi oldukça önemlidir. Pazarlama literatüründe müşteri davranışlarının anlaşııması için davranışsal teorilerden yararlanılır. Davranışsal teorilerden üretilen birçok model ile müşterilerin yeni teknolojileri daha kolay benimsemesi sağlanmaktadır. Böylelikle müşterilerin yeni ürün ve hizmetleri kullanımında karşılaştıkları yeni teknolojileri engeli aşılabilmektedir. (Türker, 2019:3-4)

Bankacılık sektörü de teknolojik gelişmeler ışı̆̆ında mobil uygulamalarını geliştirmek için ciddi yatırımlar yapmaktadır. Türkiye Bankalar Birliği Mart 2020 (TBB, 2020) raporuna göre Mobil bankacılık hizmetini kullanmak için sistemde kayıtlı olan ve sisteme en az bir kez giriş gerçekleştirmiş olan toplam müşteri sayısı Mart 2020 itibariyle yaklaşık 83 milyon kişidir. Bu müşterilerden 52 milyon 481 bin kişisi (yüzde 63'ü) ocak-mart 2020 dönemi içerisinde en az bir kez sisteme giriş gerçekleştirmiştir. Bankaların daha başarılı olabilmeleri için en az bir kere giriş yapmış olan kişilerin devamlılığının sağlanması gerekmektedir. Çalışmamızda bu devamlılığın nasıl sağlanabileceğini; Mobil bankacılı̆ın, banka müşterileri tarafından kabul ve benimsemesine yönelik davranışsal niyetini, mobil uygulama kabul modeli ile ortaya koymaya çalıştık.

\section{LITERATÜR ÖZETi}

\subsection{Mobil Bankacılık}

Günümüz teknoloji çağında, akıllı telefon kullanımının artmasıyla birlikte bankaların, internet vasıtası ile akılı telefon veya akılı tabletler üzerinden müşterilerine erişim sağladığı kanala mobil bankacılık denir. Internet bankacılığında sunulan neredeyse tüm hizmetler mobil bankacılıkta da sunulmaktadır. Ancak akıllı telefon ve tabletlerin boyutlarının küçük olması nedeniyle bazı hizmetler kısıtlanmıştır. Mobil bankacılık, bankadan bankaya değişen mobil şube, cep bank, cep şube gibi isimlerle nitelendirilmektedir. Bu bankacılık türünün en önemli avantajı ise, müşterinin istediği zaman ve istediği yerde akıllı telefonunu kullanarak hesaplarına erişebilmesidir. (Özkan ve İpekten, 2017: 649-650). 
Mobil bankacılık, finans hizmetlerinin mobil iletişim aygıtlarının yardımıyla yapılmasına imkân sağlamaktadır. Verilen hizmetler yatırım operasyonları, hesap verilerine ulaşma, para transferi gibi farklı banka işlemlerini kapsamaktadır. Mobil bankacılığa yönelik farkındalık yaratılması ve pozitif tutum gösterilmesinde cep telefonlarının yaygınlıkla kullanımı, iktisadi gelişmelerle mobil hizmetlerin artık bir ihtiyaç olması, genç kuşakların çağdaş iletişim hizmetlerine ilgi göstermeleri ve cep telefonu teknolojilerinin gelişmesi etkin olmuştur (Paçan Özcan, Sabah Çelik ve Özer, 2019: 476-477). Başarılı mobil uygulamalar değerlendirildiğinde, bu hizmetlerde müşteri de kazanıldığı gözlemlenmektedir. Bu özellikler (Doğan, 2012: 34);

a. Kimlik teyidi, aygıtların yitirilmesi durumunda da içeriklerin kolaylıkla silinmesini temin eden hizmetler,

b. Sembollerin kullanıldığı kullanıcılar için avantajlı ara yüzler,

c. Satış yerlerinde hızlı bir şekilde ödemelerin gerçekleşmesini sağlayan ve temasa gerek kalmayan ödeme sistemleri,

d. Aktif kredilerin kullandırılması ve satış birimlerinde yeni ürünleri bireylere sunma olanakları,

e. Hesap dinamiklerinin günün her saati takibi ve bireylere uyarı gönderme hizmetleri,

f. Az maliyetli bedellerin cep telefonlarıyla ödenebilmesini temin eden hizmetler,

g. Hesaplarla ilgili bilgilerle borç verilerine gerçek zamanlı ulaşım ve fatura ödemeleri,

h. Banka hizmetlerine zaman ve mekân kısıtlaması olmadan erişim.

Mobil bankacılığın avantajlarından yararlanabilmek ve bunları fırsata çevirebilmek için ise bazı stratejilere önem verilmesi gerekmektedir. Başarılı bir mobil bankacılık stratejisi için öncelikle akıllı telefonların penetrasyonu olanağı ile tüketici beklentilerinin yerinde ve doğru belirlenmesi gerekmektedir. Bankaların sürekli olarak en iyi mobil bankacılık stratejilerini gözden geçirmeleri ve müşteri ihtiyaçlarını karşılayan ve kanalın avantajlarından yararlanan yeni çözümler bulmaları gerekmektedir. Çevrimiçi bankacılık sadece bir akıllı telefon kullanmakla kalmamakta, aynı zamanda müşteri ilişkilerinin de merkezinde yer almaktadır. Örneğin Forrester Research danışmanlık firması, bankalara başarılı bir mobil bankacılık stratejisinin geliştirilmesi ve uygulanmasında yardımcı olmak için bir “Mobil Bankacılık Stratejisi Başucu Kitabı” geliştirmiştir (Gjino ve Findiku, 2014: 45-46). Kitap’a göre mobil bankacılık alanına ilişkin bazı tespitler şu şekildedir (Forrester, 2019: 9-10);

- Bankalar dijital dönüşüm baskısı altındadır. Bankalardaki küresel hizmet karar vericilerinin yaklaşık \% 70'i ya şu anda dijital dönüşüm geçirmekte ya da kendilerini sürekli dijital dönüşüm halinde göreceklerdir. Bankaların \% 34'ü önümüzdeki 12 ay içinde dijital işlerini hızlandırmayı yüksek veya kritik bir öncelik olarak görmektedir. Ancak dijital dönüşüm, rakipler, kısa vadeli hedefler ve hizmetlerin nitelikleri, müşteri beklentileri vb. bakımından kolay bir süreç değildir.

- Dijital dönüşüm genellikle liderler değil, teknoloji tarafından yönlendirilir. Bankaların \% 47'sinde bu işle görevli alanında uzman kişiler görev yapmaktadır. Dijital dönüşümde klasik yönetici reaksiyonundan ziyade teknolojiyi takip ederek ayak uydurmayı başaran CTO statüsündeki daha çok operatif kişiler etkilidir.

- Maliyet azaltma ve müşteri kazanımı, dijital dönüşümün ana itici güçleridir. Dijital müşteri deneyimi platosunun getirileri ve borç verme artışı gibi temel iş kollarındaki marj baskısı olarak, bankalar daha fazla operasyonel verimlilik yoluyla müşterilere hizmet maliyetini azaltmaya odaklanılmaktadır.

- Kültür, dijital dönüşüm için en büyük zorluklardan biri olmaya devam etmektedir. Forrester, kültürü "davranışı yönlendiren bir dizi paylaşılan değer ve inanç" olarak tanımlamaktadır. Birçok bankanın dijital girişimleri, kuruluş genelinde kültürel uyum eksikliği nedeniyle geri çekilmektedir. Bu yanlış hizalama genellikle riskten kaçınma, ürün odaklı kararlar, satış odaklı kültür, sessiz çalışma modelleri ve hiyerarşik hesap verebilirlik gibi yanlış davranışlara ve değerlere yol açmaktadır.

- Güven ve güvenlik kaygıları ve görece eski teknolojiler bankaların çabalarını engelleyebilmekte ve ayrıcı bunlar son derece önem arz etmektedir. Yükselen siber saldırılar, açık bankacılık ve düzenleyici üçüncü taraf erişiminin ortaya çıkmasıyla, bankaların müşteri etkileşimleri üzerinde daha az kontrole ve "haydut" bir üçüncü taraf aracılığıyla daha fazla riske maruz kalma durumu söz konusu olabilmektedir. Bu da bankaları müşterinin güvenliği ve bütünlüğü konusunda haklı olarak endişelendirmektedir.

\subsection{Türk Bankacılık Sektörünün Dijital Bankacılık ìstatistikleri}

Türkiye'de Mayıs 2020 itibariyle 32 adet Mevduat Bankası ve 6 adet Katılım Bankası faaliyet göstermektedir. Bu bankaların listesi Tablo 1'de gösterilmiştir. 
Tablo 1: Türkiye'deki Mevduat ve Katılım Bankaları

\begin{tabular}{|l|l|l|l|}
\hline Mevduat Bankaları & Mufg Bank Turkey A.Ş. & Alternatifbank A.Ş. & Katılım Bankaları \\
\hline Akbank T.A.Ş. & Anadolubank A.Ş. & Qnb Finansbank A.Ş. & Kuveyt Türk Katılım Bankası A.Ş. \\
\hline Odea Bank A.Ş. & Rabobank A.Ş. & Bank Mellat & Türkiye Emlak Katııım Bankası A.Ş \\
\hline Arap Türk Bankası A.Ş. & Bank Of Chına Turkey A.Ş. & Şekerbank T.A.Ş. & Türkiye Finans Katıım Bankası A.Ş \\
\hline Socıete Generale S.A. & T.C. Ziraat Bankası A.Ş. & Cıtıbank A.Ş. & Vakıf Katılım Bankası A.Ş. \\
\hline Burgan Bank A.Ş. & Denizbank A.Ş. & Turkland Bank A.Ş. & Ziraat Katıım Bankası A.Ş. \\
\hline Turkısh Bank A.Ş. & Türk Ekonomi Bankası A.Ş. & Fibabanka A.Ş. & \\
\hline Deutsche Bank A.Ş. & Türkiye Halk Bankası A.Ş. & \\
\hline Türkiye Garanti Bankası A.Ş. & Habib Bank Limited & Icbc Turkey Bank A.Ş. & \\
\hline Hsbc Bank A.Ş. & Türkiye İş Bankası A.Ş. & Yapı Ve Kredi Bankası A.Ş. & \\
\hline Türkiye Vakılar Bankası & Jp Morgan Chase Bank & & \\
\hline Intesa Sanpaolo S.P.A. & Ing Bank A.Ş. & & \\
\hline
\end{tabular}

Kaynak: BDDK, (2020). Türkiye'deki Bankalar, https://www.bddk.org.tr/Kuruluslar-Kategori/Bankalar/1, E.T. 06.05.2020

Türkiye'nin dijital bankacılık görünümüne bakıldığında Türkiye Bankalar Birliği Mart 2020 raporuna (TBB, 2020 ) göre "Ocak-Mart 2020 dönemi içinde toplam (bireysel ve kurumsal) aktif dijital bankacılık müşteri sayısı 56 milyon 324 bin kişidir. Bu sayının yaklaşık 4 milyon kişisi 'sadece internet bankacılığı' işlemi yaparken, 44 milyonu 'sadece mobil bankacılık' işlemi yapmıştır. Hem internet hem mobil bankacılık işlemi yapan kullanıcı sayısı ise 8 milyon 412 bin kişidir. Bununla birlikte Ocak-Mart 2020 dönemi içinde az bir kez giriş (log-in) işlemi yapmış aktif bireysel dijital bankacılık müşteri sayısı 53 milyon 981 bin kişidir. Bu sayının 3 milyon 154 bin kişisi 'sadece internet bankacılığı' işlemi yaparken 43 milyon 61 bin kişisi 'sadece mobil bankacılık' işlemi yapmıştır. Hem internet hem mobil bankacılık işlemi yapan kullanıcı sayısı ise 7 milyon 766 bin kişidir. Aktif bireysel dijital bankacılık müşterileri, 37 milyon 125 bin kişi erkek (yüzde 69), 16 milyon 857 bin kişi kadın (yüzde 31) müşterilerden oluşmaktadır. Ocak-Mart 2020 dönemi içinde aktif bireysel dijital bankacılık müşterilerin yaş grupları bazında dağılımında ilk sırayı 21 milyon 152 bin kişi ile 36-55 yaş grubu almaktadır. Bunu, 15 milyon 976 bin kişi ile 26-35 yaş grubu, 11 milyon 274 bin kişi ile 18-25 yaş grubu izlemektedir. 5665 yaş grubundaki aktif bireysel dijital bankacılık müşteri sayısı ise 3 milyon 896 bin kişidir. Ocak-Mart 2020 dönemi içinde az bir kez giriş(log-in) işlemi yapmış aktif kurumsal dijital bankacılık müşteri sayısı 2 milyon 343 bin kişidir" (s. i).

Türkiye'deki internet bankacılığını kullanan müşteri sayısı Tablo 2'de gösterilmiştir.

Tablo 2: İnternet/Mobil Bankacılığını Kullanan Müşteri Sayısı

\begin{tabular}{|l|c|c|}
\hline & $\begin{array}{c}\text { Ekim-Aralık } \\
\mathbf{2 0 1 9}\end{array}$ & $\begin{array}{c}\text { Ocak-Mart } \\
\mathbf{2 0 2 0}\end{array}$ \\
\hline Bireysel müşteri sayısı (bin kişi) & & \\
Aktif (A) (son 3 ayda 1 kez login olmuş) & 10.714 & 10.920 \\
Kayıtlı (B) (en az 1 kez login olmuş) & 67.387 & 69.339 \\
Kayıtlı (C) (son 1 yılda en az 1 kez login olmuş) & 21.518 & 21.792 \\
Aktif (A) / kayıtlı (B) müşteri oranı (yüzde) & $\mathbf{1 6}$ & $\mathbf{1 6}$ \\
\hline Kurumsal müşteri sayısı (bin kişi) & & \\
Aktif (A) (son 3 ayda 1 kez login olmuş) & 1.271 & 1.336 \\
Kayıtlı (B) (en az 1 kez login olmuş) & 4.134 & 4.290 \\
Kayıtlı (C) (son 1 yılda en az 1 kez login olmuş) & 1.784 & 1.815 \\
Aktif (A) / kayıtlı (B) müşteri oranı (yüzde) & $\mathbf{3 1}$ & $\mathbf{3 1}$ \\
\hline Toplam müşteri sayısı (bin kişi) & & \\
Aktif (A) (son 3 ayda 1 kez login olmuş) & 11.985 & 12.256 \\
Kayıtlı (B) (en az 1 kez login olmuş) & 71.521 & 73.629 \\
Kayıtlı (C) (son 1 yılda en az 1 kez login olmuş) & 23.303 & 23.607 \\
Aktif (A) / kayıtlı (B) müşteri oranı (yüzde) & $\mathbf{1 7}$ & $\mathbf{1 7}$ \\
\hline
\end{tabular}

Kaynak: TBB, (2020b). Dijital, İnternet ve Mobil Bankacılık İstatistikleri Mart 2020,

https://www.tbb.org.tr/Content/Upload/istatistikiraporlar/ekler/1289/Dijital-Internet-Mobil Bankacilik Istatistikleri-Mart 2020.pdf,

E.T. 06.05.2020 
Yine TTB raporuna göre (TBB, 2020)

"Internet bankacılığı yapmak üzere sistemde kayıtlı olan ve en az bir kez giriş işlemi yapmış kurumsal müşteri sayısı, Mart 2020 itibariyle 4 milyon 290 bin kişi olarak gerçekleşmiştir. Bunların 1 milyon 336 bini (yüzde 31'i) Ocak-Mart 2020 dönemi içerisinde en az bir kez giriş işlemi yapmıştır. Son bir yıl içerisinde en az bir kez giriş işlemi yapmış kurumsal müşteri sayısı ise 1 milyon 815 bin kişidir. İnternet bankacılığı için kayıt yaptıran ve en az bir kez giriş işlemi yapmış toplam (bireysel ve kurumsal) müşterilerin yüzde 17'si Ocak-Mart 2020 döneminde en az bir kez internet bankacıllğı işlemi yapmıştır. Toplam (bireysel ve kurumsal) aktif müşteri sayısı bir önceki döneme göre 206 bin kişi artmıştır" (s. ii).

Aynı zamanda Mart 2020 itibariyle Türkiye'de internet bankacılığı üzerinden yapılan işlemlere bakıldığında (TBB, 2020) (Tablo 3)

"Ocak-Mart 2020 dönemi itibariyle, internet bankacılığı hizmeti kullanılarak yapılan finansal işlemlerin toplam adedi 111 milyon, tutarı ise 1,5 trilyon TL TL'dir. EFT, havale ve döviz transferi işlemlerini kapsayan para transferleri işlemleri, 1 trilyon TL işlem hacim ve 56 milyon işlem adedi ile finansal işlemler arasında en büyük paya sahip olmuştur (finansal işlem hacminin yüzde 67'si). İkinci sırada 364 milyar TL'lik işlem hacmi ve 17 milyon işlem adedi ile yatırım işlemleri bulunmaktadır" (s. ii-iii).

İnternet bankacılığı ile yapılan finansal işlemlerin büyüklüğü ise 40 milyar TL civarında artış göstermiştir (TBB, 2020).

Tablo 3: İnternet/Mobil Bankacılığında Finansal İşlemler

\begin{tabular}{|c|c|c|c|c|}
\hline & \multicolumn{2}{|c|}{ Ekim-Aralık 2019} & \multicolumn{2}{|c|}{ Ocak-Mart 2020} \\
\hline & $\begin{array}{c}\text { İşlem Adedi } \\
\text { (Milyon) }\end{array}$ & $\begin{array}{c}\text { İşlem Hacmi } \\
\text { (Milyar TL) }\end{array}$ & $\begin{array}{c}\text { İşlem Adedi } \\
\text { (Milyon) }\end{array}$ & $\begin{array}{c}\text { İşlem Hacmi } \\
\text { (Milyar TL) }\end{array}$ \\
\hline Para transferleri & 66 & 1.066 & 56 & 1.022 \\
\hline Ödemeler & 30 & 62 & 28 & 65 \\
\hline Yatırım işlemleri & 13 & 286 & 17 & 364 \\
\hline Kredi kartı işlemleri & 8 & 23 & 7 & 22 \\
\hline Diğer finansal işlemleri & 4 & 55 & 4 & 59 \\
\hline Toplam & 120 & 1.492 & 111 & 1.532 \\
\hline
\end{tabular}

Kaynak: TBB, (2020b). Dijital, İnternet ve Mobil Bankacılık İstatistikleri Mart 2020

https://www.tbb.org.tr/Content/Upload/istatistikiraporlar/ekler/1289/Dijital-Internet-Mobil Bankacilik Istatistikleri Mart_2020.pdf, E.T. 06.05.2020

\subsection{Mobil Bankacılık Açısından Teknoloji Kabul Modeli}

Işletmeler ve kurumların verdikleri hizmetlere ya da arz ettikleri mamullere ilişkin, internet başta olmak üzere uzaktan erişim, hizmet sağlama ve uygulamalar gibi süreçlerde teknoloji kullanılmaktadır. Karşı tarafın (müşteri veya kullanıcı) bu teknolojileri benimseme durumunu modelleyen teknoloji kabul modeli son yıllarda dikkat çeken konular arasındadır. Zira işletme veya kurumların arz ettikleri ürün/hizmet süreçlerini teknoloji tabanlı süreçlere uyarlaması kadar bunların kullanıcılar tarafından da benimsenmesi gerekmektedir.

Çalışmanın bu başlığı altında bankalar tarafından sağlanan yeni teknolojiler ve mobil araç veya uygulamaların müşteriler tarafından benimsenmesinde kabul ve ret tutumlarının arka planındaki dinamiklere ilişkin kuramsal modeller incelenmiştir. Söz konusu modeller teknolojiye dayalı iş ve hizmetler sunan sadece bankalar açısından değil tüm kurum ve işletmeler için geçerlidir.

Mobil uygulama ve içerikler teknolojinin gelişimine paralel olarak bilişim alanında da kendini göstermiştir. Böylelikle bir çok iş mobil alana taşınarak dijitalleştirilmiştir. İşletmeler, müşterileri ve çözüm ortakları ile daha hızlı ve entegre temas kurabilmek, anlık geri bildirim alabilmek, en hızlı ve en uygun maliyetle işleri yönetebilmek için elektronik alt yapıları çok daha fazla kullanabilmek için ciddi çaba sarf etmektedirler (Yıldırır ve Kaplan, 2019: 24). Hatta son zamanlar bu amaçla blok zincir (block chain) adı verilen yeni nesil teknolojileri devreye alarak tamamen dijitalleşen bir iş modeline doğru geçiş süreci yaşandığı görülmektedir (Gambhir, Bevan ve Devemport, 2018: 2-4). Internet tabanlı teknoloji ve uygulamaların karşı tarafça, yani bankacılık açısından, müşterilerce de kullanılması gerekmektedir.

Serçemeli ve Kurnaz'a (2016) göre TKM'nin temel amacı bireylerin bilgisayar kullanırken gösterdikleri davranışları geniş bir yelpazede açıklamaktır. Ayrıca model bilgisayar kullanımı esnasında bireylerin tutucu, kemikleşmiş davranışlarını da açıklamayı hedefleyen bir modeldir. Araştırmacılar ve uygulamacılar başarılı bir modelin tahmine yönelik olması ile beraber açıklayıcı da olmasının gerektiğini vurgulamaktadırlar. Dolayısıyla TKM’nin Temel hedefi niyetlerin, tutumların ve içsel inançların üzerinde etkili 
olan dışsal faktörlerin etkisini açıklamaktır. TKM'nin bir diğer amacı " $n$ " sayıdaki değişkenle bilgisayar (ya da BT kullanıcıları) kullanıcılarının teknoloji benimsemeye yönelik kabul veya ret davranışına yol açan nedenlerin çözümlenebilmesidir. Davis (1989) tarafından geliştirilen (Şekil 1) TKM, birbiriyle ilişkilerinin ölçüldüğü veya etkileşiminin incelendiği; uygunluk/uyumluluk, algılanan kullanışılık, algılanan kullanım kolaylığı, tavır niyeti, davranış niyeti ve sistem kullanımı olmak üzere altı faktörden oluşmaktadır (Yıldırır ve Kaplan, 2019: 24).

\section{Şekil 1: Teknoloji Kabul Modeli}

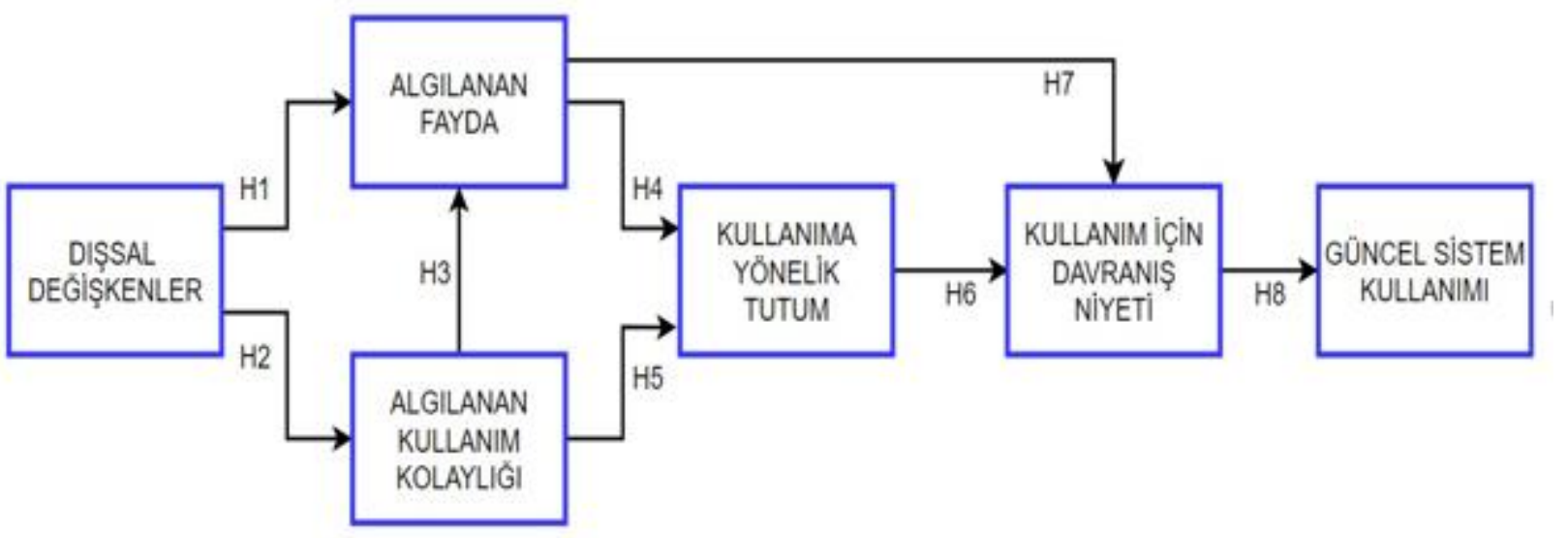

Kaynak: Davis (1989)'dan Akt. Akça ve Özer, 2012: 82.

\subsection{Mobil Uygulama Kabul Modeli}

Finansal hizmetlerin de arasında yer aldığı, ürün, hizmet, süreç ve diğer teknolojik yeniliklerin kabulüne ilişkin yapılan çalışmaları beş kategoride sınıflamak mümkündür. Birinci kategoride yer alanlar için "yenilikçiler" sıfatı kullanılabilir. Bu kişilerin yeni gelişme ve teknolojilere yakın olduğu, bunları sıklıkla kullandığı ifade edilebilir. İkinci kategoride yer alanlar için "öncüler" ifadesi kullanılabilir. Bu kişiler "yenilikçilerin" benimsediği gelişmeleri yayan ve deneyimlerini paylaşanlar olarak kabul edilebilir. Üçüncü kategoride yer alanlar için "erken çoğunluk" nitelemesi yapılabilir. Bunlar için "yenilikçiler" ile "öncüler" arasındaki kişiler olup yeni olan bir fikri benimsemeden önce düşünen kişilerdir denilebilir. Dördüncü kategoride yer alanlar için "çekimserler" demek mümkündür. Bunlar için geç veya sınırlı kullanım/katılım gösteren risk algısı taşıyan ve teknolojiye görece uzak kişiler olarak kabul edilebilir. Beşinci kategoride yer alanlar ise "soyut" olarak nitelenebilir. Bu kişilerin alışkanlıklarına bağlı oldukları gibi teknik gelişmeleri kabul konusunda oldukça mesafeli olduğu söylenebilir. Elbette bu sınıflama ve kategorik önerme tartışmaya açık olmakla birlikte, yeni şeyler hakkında kişilerin kültür, yaş, statü, eğitim, meslek vb. gibi değişkenlerinde dikkate alınması gerekmektedir.

Yapılan bu sınıflama yukarıda açıklanan modellerde, bazı değişkenler açısından yer almakla birlikte gereksinimleri, algılanan fayda, performans beklentisi, öznel durumlar/normlar, kullanıma yönelik tutumlar ve niyetler bakımından daha kapsayıcı bir açıklama veya modelin kurulması gerekmektedir. Bu amaçla Uğur ve Turan (2016) tarafından Mobil Uygulama Kabul Modeli (MUKM) ileri sürülmüştür. Mobil Uygulama Kabul Modeli (MUKM) "önceki başlıkta açıklanan modellerin bileşkesi olarak görülebilecek bir yaklaşımdı" denilebilir. Bireylerin mobil bankacılık dahil olmak üzere mobil uygulamaları kullanma ve kabul etme davranışları üzerinde etkili olan faktörleri ortaya koyan MUKM, Teknoloji Kabul ve Kullanım Birleştirilmiş Modeli (TKKBM), Planlı Davranış Teorisi (PDT), Kullanımlar ve Doyumlar Yaklaşımı (KDY) ve Teknoloji Kabul Modeli (TKM) kullanılan değişkenlerin ilişkisel düzeyde birleştirilmesinden oluşmaktadır. Öncelikle bahsi geçen değişkenler ve ardından Model hakkında açıklamalar yapılmıştır. 


\subsubsection{Teknoloji Kabul ve Kullanım Birleştirilmiş Modeli}

Teknoloji Kabul ve Kullanım Birleştirilmiş Modeli (TKKM), Venkatesh vd., (2003) tarafından ileri sürmüştür. Bilgi,psikoloji ve sosyoloji araştırmalarından esinlenerek model ortaya çıkarılmıştır. TKKM, her bir modelin birleşik açıklayıcı gücünü ve kilit düzenleyici etkilerini kapsamakta ve temel TKM ni koruyarak oluşturulmuştur. Modeldeki ana değişkenler cinsiyet, yaş, gönüllülük ve tecrübe olarak belirtilmiştir. Literatürde yaş ve cinsiyet değişkenine çoz az bahsedilirken, TKKM ile önemli etkileri olduğu görülmüştür. (Gürses, 2016: 56-59).

\subsubsection{Planlı Davranış Teorisi}

Planlı Davranış Teorisi (PDT) bir teknolojinin ortaya çıkması ile bireylerin, tutum ve davranış biçimlerini inceleyen bir teori olan Planlı Davranış Teorisi (PDT), Ajzen (1991) tarafından oluşturulmuştur. PDT, sosyal ve davranış bilimlerinin içerisinde yer almaktadır. Sosyal bilimlerin içerisinde ise özellikle pazarlama alanında tüketicilerin ürün ya da marka satın alması, mağazadan alışveriş yapması, bir ürün hakkında bilgi araması gibi davranışlarının incelenmesi çalışmalarında da sıklıkla kullanılan bir model olduğu ifade edilmektedir. İnsan davranışlarını tahmin etmede tutum ve algılanan davranışsal kontrol gibi kişisel faktörler, öznel norm gibi sosyal faktörleri içinde barındırmaktadır. PDT'de bahsedilen faktörler bağlamında niyeti etkileyen üç belirleyici değişken bulunmaktadır. Bu değişkenler tutum, öznel norm ve algılanan davranışsal kontroldür (Özer, Kement ve Gültekin, 2015:62).

\subsubsection{Teknoloji Kabul Modeli}

Teknoloji kabul modeli, kullanıcıların bir bilgi sistemini kabul etme ve reddetme nedenlerini kullanıcıların algılarına göre izah eder. Davis (1989), Teknoloji kabul modelini, Ajzen ve Fishbein (1975)'in niyetlerin nasıl davranışa dönüştüğünü açılamada ve tahmin etme noktasında başarılı olan Gerekçeli Eylem Teorisinden esinlenerek geliştirmiştir. Teknoloji Kabul Modeli, Gerekçeli Eylem Teorisinin bir uyarlamasıdır.

Teknoloji Kabul Modeli özellikle bilgi teknolojilerinin kullanıcılar tarafından kabulünü açıklayan ve ele alan bir model olarak öne çıkmaktadır. Gerekçeli eylem teorisini temel alan bu modelde algılanan fayda, algılanan kullanım kolaylığı, kullanmaya yönelik tutum, kullanmaya yönelik davranışsal niyet ve gerçek kullanım arasındaki nedensel ilişkiler açıklanmaya çalışılmaktadır. Gerekçeli eylem teorisi ile TKM arasında benzerlikler olmasına karşın davranışın açıklanmasında teorik olarak farklılıklar vardır. Her iki modelde davranışa yönelik tutumun konu ile ilgili inançları tarafından belirlendiğini varsaymaktadır. Ancak gerekçeli eylem teorisi kullanılarak tutumun belirleyicilerini ortaya çıkaran inançlar genel değildir. Sadece o konuya özel inanç unsurlardır (Yılmaz ve Kavanoz, 2017: 131-132).

\subsubsection{Kullanımlar ve Doyumlar Yaklaşımı}

Kökenlerin 1940'ı yıllara kadar geriye giden Kullanımlar ve Doyumlar Yaklaşımı (KDY), iletişim alanındaki çalışmaların ilk yıllarında kitle iletişim araçlarının toplum üzerindeki sınırsız etki meydana getirdiği önermesini ileri sürmüştür. İletişim kaynağının temel yönlendirici olduğu, mesaj alıcısının da buna bağlı olarak edilgen olduğu varsayımından hareket etmiştir. Daha sonra bu yaklaşımın geçerliği zayıflamış, iletişim araçlarının merkezde olduğu bir konumdan, izleyicinin merkezde olduğu bir konuma geçilmiştir (Güngör, 2016: 123-126).

1950 ve 1960 yıllardan itibaren izleyicilerin edilgen olmadığı, bilinçli kararlar verdiği, kendi iradelerini ortaya koyduğu yapılan araştırmalarla tespit edilince KDY tamamen geçersiz hale gelmese de etkisinin oldukça zayıfladığı belirtilmektedir (Özer ve Birsen, 2010: 352). KDY temel olarak insanların gereksinmelerinin karşılanarak doyuma ulaştırılması gerektiği düşüncesinden hareket etmiştir (Uğur ve Turan, 2016: 102). Yapılan açıklamalardan yola çıkarak Uğur ve Turan (2016) Mobil Uygulama Kabul Modeli (MUKM) ileri sürmüşlerdir. Daha önce de ifade edildiği gibi TKM 'ne TKKBM, KDY ile PDT modellerinde yer alan bazı değişkenler ilave edilerek Şekil 2 gösterilen model oluşturuldu. 


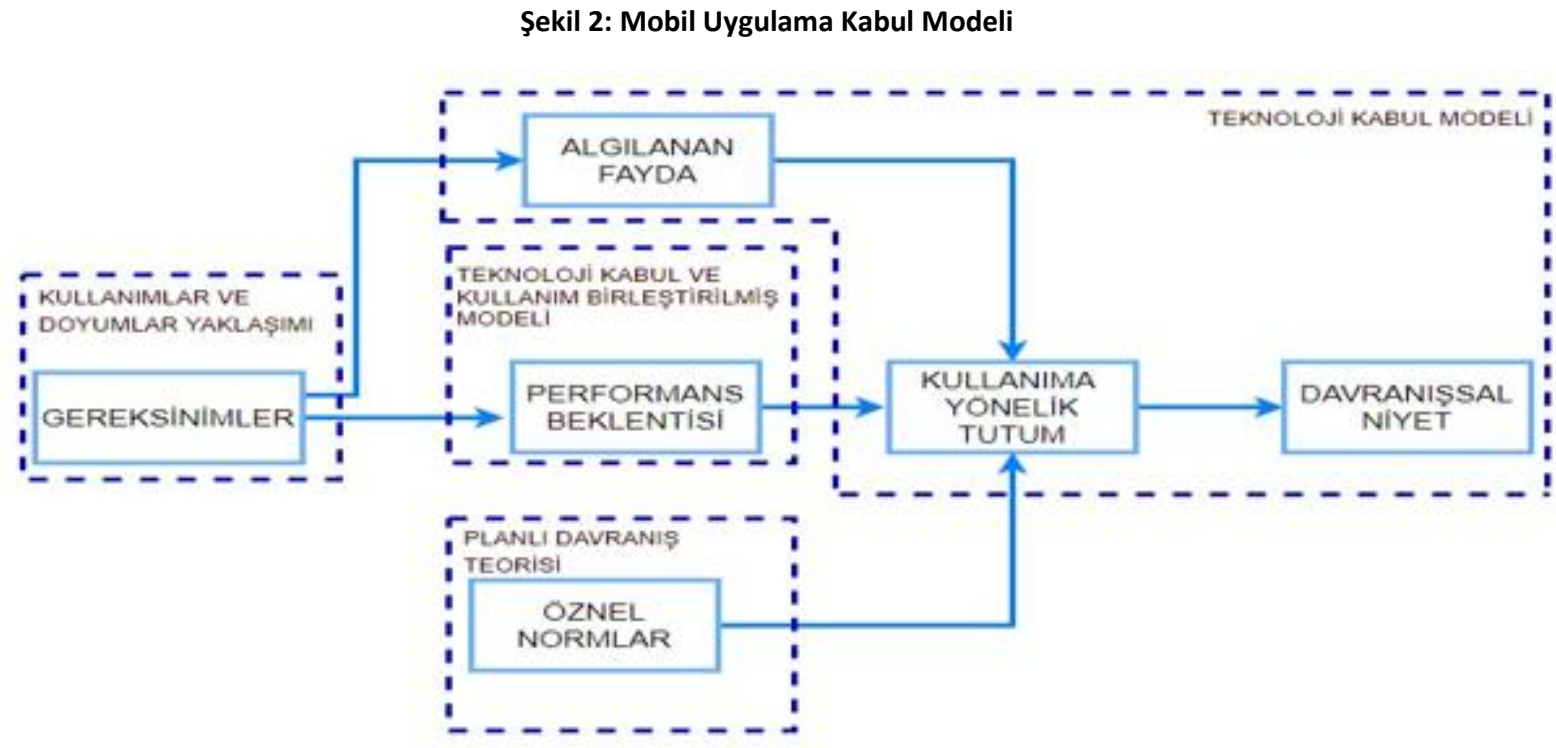

Kaynak: (Uğur, N. G. ve Turan, A. H. (2016). Mobil Uygulama Kabul Modeli: Bir Ölçek Geliştirme Çalışması, Hacettepe Üniversitesi iiBF Dergisi, 34 (4), 107).

Tablo 4: Mobil Uygulama Kabul Modeli Değişkenleri ve Kapsamı

\begin{tabular}{|c|c|}
\hline Değişken Adı & Tanımı ve Kapsadığı Unsurlar \\
\hline Davranışsal Niyet & 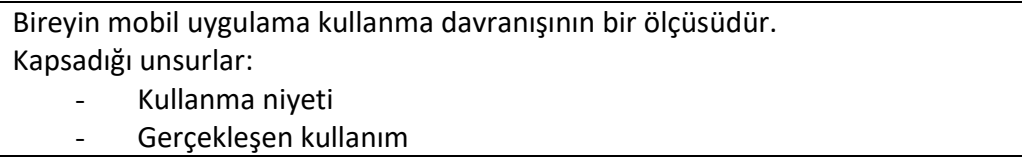 \\
\hline Kullanıma Yönelik Tutum & $\begin{array}{l}\text { Bireyin mobil uygulama kullanmaya yönelik olumlu ya da olumsuz } \\
\text { değerlendirmeleridir. } \\
\text { Kapsadığı unsurlar: } \\
\quad \text { Benimseme eğilimi } \\
-\quad \text { Benimseme isteği } \\
-\quad \text { İçsel Motivasyon }\end{array}$ \\
\hline Öznel Normlar & 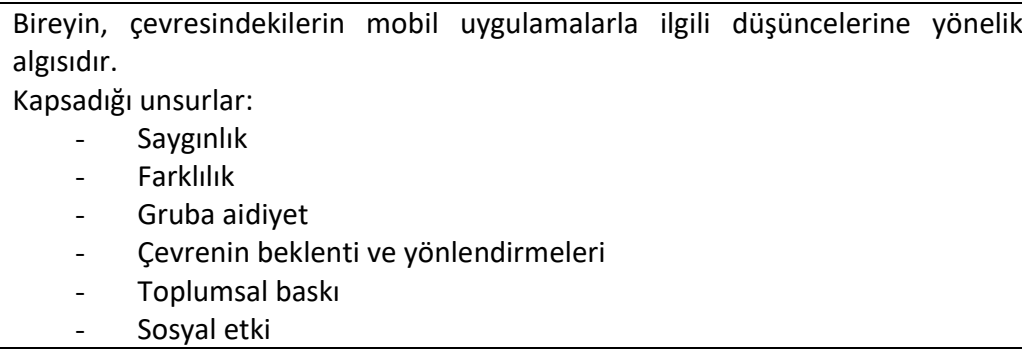 \\
\hline Performans Beklentisi & 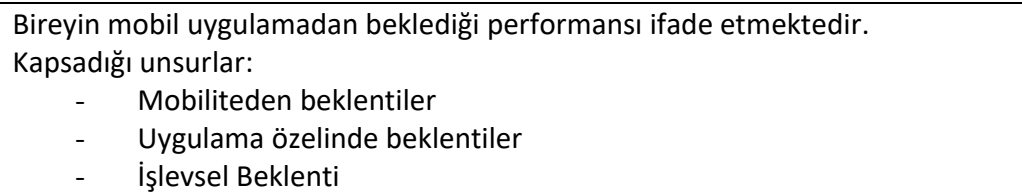 \\
\hline
\end{tabular}




\begin{tabular}{|l|l|}
\hline Algılanan Fayda & Bireyin mobil uygulamanın işlerine veya günlük yaşantısına fayda sağlamasıyla \\
& ilgili beklentilerini ifade eder. \\
& Kapsadığı unsurlar: \\
- & Ilgili avantaj \\
- & İşlevsel getiri \\
& $-\quad$ Kişisel verimlilik artışı \\
& - Dışsal Motivasyon \\
\hline Gereksinimler & Bireyi mobil uygulama kullanmaya yönelten ve doyuma ulaşması amaçlanan \\
& ihtiyaçları ifade eder. \\
& Kapsadığı unsurlar: \\
& $-\quad$ İş görebilirlik \\
& $-\quad$ Doyuma ulaşması gereken ihtiyaçlar \\
& $-\quad$ intiyaçların karşılanması \\
\hline
\end{tabular}

Kaynak: Uğur, N. G. ve Turan, A. H. (2016). Mobil Uygulama Kabul Modeli: Bir Ölçek Geliştirme Çalışması, Hacettepe Üniversitesi iiBF Dergisi, 34 (4), : 107

\section{METADOLOJi}

\subsection{Araştırma Modeli ve Hipotezler}

Teknolojinin sürekli gelişmesi, teknolojinin kolay kullanımının önemini artırmıştır. Farklı disiplinlerde kullanııların yeni teknolojileri kabullenmeleri ile ilgili birçok araştırmalar yapılmış ve çok sayıda model ortaya konmuştur. Bunlardan bazıları Teknoloji Kabul Modeli (Davis vd., 1989), Yeniliklerin Yayılması Teorisi (Rogers, 1995), Birleştirilmiş Teknoloji Kabul Modeli ve Planlı Davranış Teorisi (Taylor ve Todd, 1995), Birleştirilmiş Teknoloji Kabul ve Kullanım Teorisi'dir (Venkatesh vd., 2003).

Yukarıda açıklanan modellerde, bazı değişkenler yer almakla birlikte gereksinimleri, algılanan fayda, performans beklentisi, öznel durumlar/normlar, kullanıma yönelik tutumlar ve niyetler bakımından daha kapsayıcı bir açıklama veya modelin kurulması gerekmektedir. Bu amaçla Uğur ve Turan (2016) tarafından Mobil Uygulama Kabul Modeli (MUKM) ileri sürülmüştür. Bireylerin mobil bankacılık dahil olmak üzere mobil uygulamaları kullanma ve kabul etme davranışları üzerinde etkili olan faktörleri ortaya koyan MUKM, Teknoloji Kabul ve Kullanım Birleştirilmiş Modeli (TKKBM), Planlı Davranış Teorisi (PDT), Kullanımlar ve Doyumlar Yaklaşımı (KDY) ve Teknoloji Kabul Modeli (TKM) kullanılan değişkenlerin ilişkisel düzeyde birleştirilmesinden oluşmaktadır.

Modelin, bireylerin mobil uygulamaları kabullenmesinde etkili olduğu varsayılan üç aşamalı yaklaşım kullanılarak açıklanabileceğini ileri süren Uğur ve Turan (2016: 107); “ilk aşamada modele KDY’den entegre edilen gereksinimler değişkeni yer almaktadır. Bu değişkenin algılanan fayda ve performans beklentisi değişkenleri üzerinde etkili olduğu öne sürülmektedir. İkinci aşamada ise kullanıma yönelik tutumu etkileyen inançlar olarak algılanan fayda, performans beklentisi ve öznel normlar bulunmaktadır. Üçüncü ve son aşamasa ise kullanıma yönelik tutuma yer verilmiştir. Bir başka deyişle modelde kullanıma yönelik tutum, öznel normlar ile gereksinimlerin etkisinde kalan algılanan fayda ve performans beklentisinin, davranışsal niyet üzerindeki etkisine aracılık etmektedir" şeklinde açıklama yapmışlardır.

Çalışmada değişkenler arasında ilişkiyi ortaya koyabilmek amacıyla Şekil 3’ de verilen model tercih edilmiştir. 


\section{Şekil 3: Araştırma Modeli Mobil Uygulama Kabul Modeli}

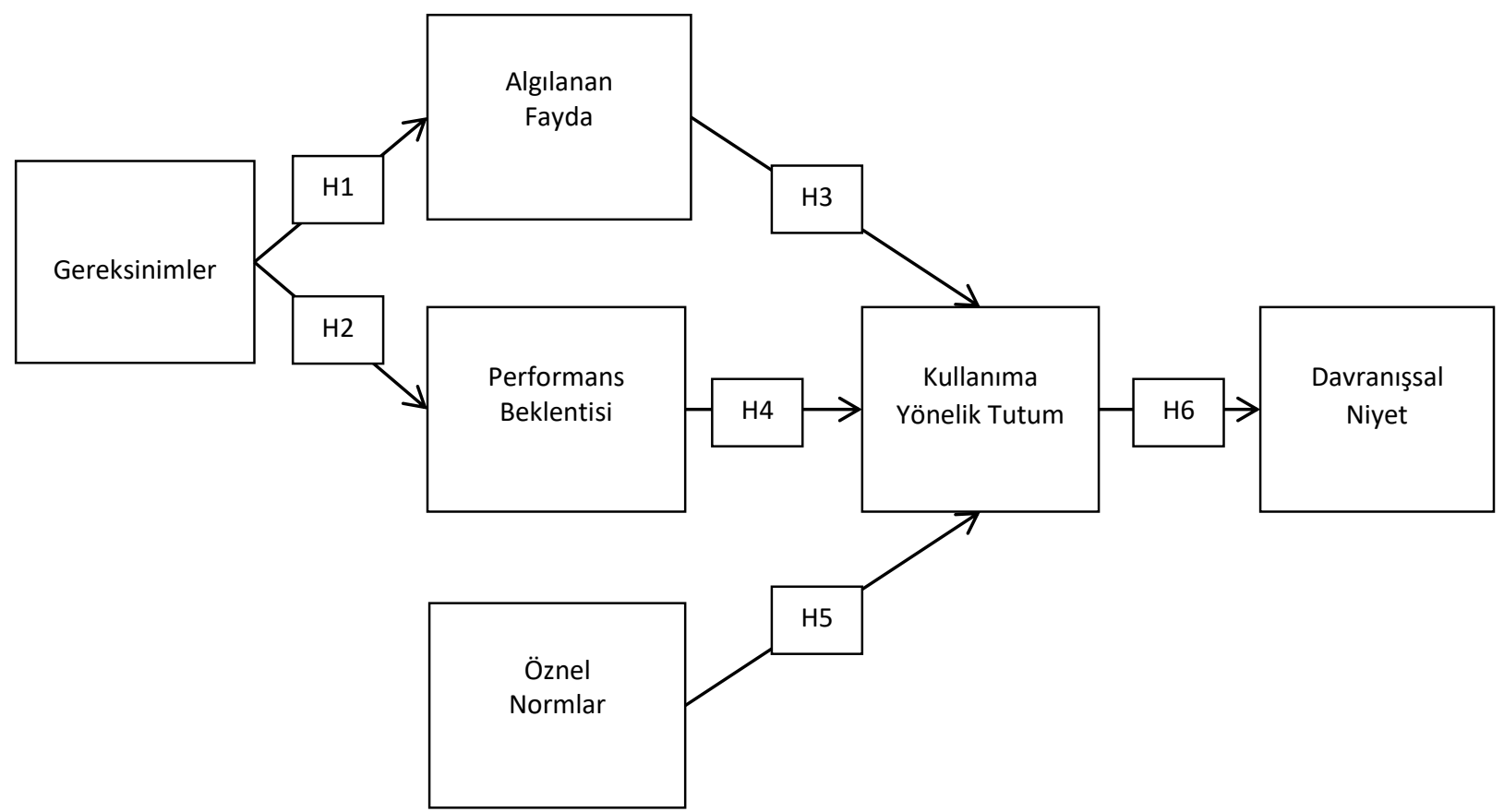

Kaynak: Uğur, N. G. ve Turan, A. H. (2016). Mobil Uygulama Kabul Modeli: Bir Ölçek Geliştirme Çalışması, Hacettepe Üniversitesi iiBF Dergisi, 34 (4),:107

\section{Hipotezler}

H1: Gereksinimler(G) mobil bankacılık kullanımına ait Algılanan Fayda(AF) üzerinde anlamlı bir etkisi vardır.

H2: Gereksinimler(G) mobil bankacılık kullanımına yönelik Performans Beklentisi (PB) üzerinde anlamlı bir etkisi vardır.

H3: Algılanan Fayda (AF) mobil bankacılık Kullanıma Yönelik Tutum (KYT) üzerinde anlamlı bir etkisi vardır.

H4: Performans Beklentisi(PB) mobil bankacılık Kullanıma Yönelik Tutum(KYT) üzerinde anlamlı bir etkisi vardır.

H5: Öznel Normlar (ÖN) mobil bankacılık Kullanıma Yönelik Tutum(KYT) üzerinde anlamlı bir etkisi vardır.

H6: Kullanıma Yönelik Tutum(KYT) mobil bankacılık kullanımı Davranışsal Niyeti(DN) üzerinde anlamlı bir etkisi vardır.

\subsection{Araştırmanın Amacı ve Sınırlılıkları}

Araştırmanın amacı Mobil bankacılığın, banka müşterileri tarafından kabul edilmesine ve benimsenmesine yönelik davranışsal niyetini, mobil uygulama kabul modeli ile ortaya koymaktır.

Böylelikle banka müşterilerinin mobil bankacılığı kullanmama nedenlerini bulup, mobil bankacılık kullanım oranlarının artmasını sağlamaktır. Aynı zamanda mobil bankacılığın, müşteriye sağladığı faydayı ölçüp, müşteri memnuniyetini en üst seviyeye çıkartmaktır.

Bu çalışma banka müşterilerinin banka işlerini bu uygulamalar üzerinden yapmalarını sağlamak için bankaların nasıl bir yol izlemelerini gerektiğini gösteren öneriler sunmayı amaçlamaktadır.

Araştırmanın sınırlıklıklarını ise şöyle ifade edebiliriz.

- Araştırma mevduat bankalarının mobil bankacılık kullanan kişiler ile sınırı kalmıştır.

Araştırma Bursa'da yaşayan $\mathbf{4 4 0}$ mobil bankacılık kullanan kişiler ile sınırlı kalmıştır.

- Araştırmada veri toplama amacıyla hazırlanan Mobil Uygulama Kabul Modeli'ne ilişkin ölçekte Uğur ve Turan (2016)' ın çalışmasında ki ifade sayısına sadık kalınmıştır, sadece ifadeler ilgili sektöre uyumlu hale getirilmiştir.

\subsection{Evren ve Örneklem}

Araştırma evrenini Bursa' da yaşayan mobil bankacılık kullanan 18 yaş üstü bireyler oluşturmaktadır. Evrenin doğru şekilde tespit edilebilmesi amacıyla Bursa Nüfus Müdürlüğü resmî web sayfasından bilgi alınmıştır. TÜí' in raporuna göre 2019 yılında Bursa 
ilinin genel nüfusu 3.056.120’ dir. Bu sayının ne kadarı 18 yaş ve üstü olduğu bilinmemektedir. Bursa' da yaşayıp 18 yaş ve üstü olup mobil bankacılık kullanan kişilerin sayısı resmi olarak bilinmemektedir.

Belirlenen evrenden örneklem seçiminde kolayda örnekleme yöntemi kullanılmıştır. Kolayda örneklem yöntemi yoluyla ihtiyaç duyulan örnekleme ulaşıncaya kadar ulaşılabilen kimselerden veri toplanmaktadır (Gürbüz ve Şahin, 2016: 134). Bu araştırma için, 440 anket doldurulmuştur.

\subsection{Veri Toplama Aracı ve Verilerin Toplanması}

Veri toplama aracı olarak iki bölümden oluşan bir anket kullanılmıştır. Illk bölümde araştırmacı tarafından hazırlanan 9 adet demografik bilgi formu yer almaktadır. Bu formda cinsiyet, yaş, eğitim durumu, bankacılık işlemleri yapma sıklığı, bankaya gitme sıklığı, akıllı telefon kullanma durumu, telefonda banka uygulamasının olma durumu, mobil bankacılığı kullanma durumu ve kullanılan banka gibi sorular yer almaktadır.

İkinci bölümde ise Uygur ve Turan (2016) tarafından geliştirilen Mobil Uygulama Kabul Modelini temel alan mobil uygulama kabul ölçeği yer almaktadır. Ölçek toplam 35 madde ve 6 boyuttan oluşmaktadır. Ölçekte yer alan maddeler $5^{\prime}$ li Likert türünde olup, yanıtlar 1-Hiç katılmıyorum, 2- Kısman katılıyorum, 3-Kararsızım, 4-Kısmen katılıyorum ve 5-Tamamen katılıyorum şeklindedir.

Çalışmada kullanılan anketin uygulanması Şubat 2020 ile Nisan 2020 ayları arasında gerçekleştirilmiştir. Araştırmada hem yüz yüze görüşme ile hem de internet üzerinden çevrimiçi anket uygulamasından yararlanılarak veriler elde edilmiştir. 100 adet anket yüz yüze görüşme ile cevaplanmış, 340 adet anket internet üzerinden cevaplanmıştır. Anket formuna ait link internet üzerinden mesajlaşmaya olanak sağlayan sosyal medya hesapları üzerinden paylaşılarak katılımcılara ulaşılmaya çalışılmıştır.

\section{BULGULAR}

Çalışmaya toplamda 440 kişi katılmıştır. Ancak faktör analizi ve diğer analizler için gerçekleştirilen normallik testlerinde bazı kişilere ait verilerin normallik testini ihlal ettiği için örneklemden çıkartılmıştır. Veri setinden çıkartılan kişi sayısı 58'dir. Buradaki tüm analizler 382 kişilik veri seti üzerinden yapılmış olup demografik özellikler bu kişilere yöneliktir.

İlk olarak veri setinin faktör analizini açısından uygun olup olmadığının saptanması amacıyla Örneklem Yeterlik Testi (Test of Sampling Adequacy - KMO [Kaiser - Meyer - Olkin]) ve değişkenler arasında ilişkinin olup olmadığını test etmek amacıyla Barlett Küresellik testi (Bartlett's Test of Sphericity) gerçekleştirilmiştir. Yapılan analizler KMO örneklem yeterlik testi sonucunun $(K M O=0,866)$ örneklem sayısının faktör analizi yapabilmek için mükemmel düzeyde uygun olduğunu göstermektedir (Çokluk ve ark., 2012: 207). Ayrıca, Bartlett's küresellik testi sonuçları incelendiğinde Ki-kare değerinin istatistiksel olarak anlamlı $\left(\chi^{2}=8725,018, p=0.000\right)$ olduğu görülmektedir.

Daha sonra her bir değişkene ilişkin faktörlerin açıkladıkları ortak varyans değerleri (Communalities) incelenmiş ve "g4", "g5" ve "kyt6" kodlu maddelerin açıkladıkları ortak varyans değerlerinin düşük olduğu $(<0,50)$ tespit edilmiştir ve çıkartılmıştır. "pb1" ve "pb7" kodlu maddelerin her iki faktörde aynı anda yüklendiği ve faktör yük değerlerinin de birbirine çok yakın olduğu gözlemlenmiştir ve çıkartılmıştır. Tüm bu işlemlerden sonra AFA, ölçeğin 30 maddelik bu yeni formu için yeniden gerçekleştirilmiştir.

\section{Tablo 1: Faktör Analiz Sonuçları}

\begin{tabular}{|l|l|l|l|l|l|l|}
\hline Madde & F1 & F2 & F3 & F4 & F5 & F6 \\
\hline Dn3 &, 877 & & & & & \\
\hline Dn2 &, 866 & & & & & \\
\hline Dn1 &, 841 & & & & & \\
\hline Dn4 &, 811 & & & & & \\
\hline Dn5 &, 807 & & & & & \\
\hline Dn6 &, 713 & & & & & \\
\hline On5 & &, 891 & & & & \\
\hline On7 & &, 881 & & & & \\
\hline On4 & &, 854 & & & & \\
\hline On6 & &, 818 & & & & \\
\hline On3 & &, 814 & & & & \\
\hline On1 & &, 752 & & & & \\
\hline On2 & &, 702 & & & & \\
\hline Kyt4 & & &, 803 & & & \\
\hline Kyt3 & & &, 772 & & & \\
\hline
\end{tabular}




\begin{tabular}{|l|l|l|l|l|l|l|}
\hline Kyt7 & & &, 767 & & & \\
\hline Kyt5 & & &, 680 & & & \\
\hline Kyt2 & & &, 680 & & & \\
\hline Kyt1 & & &, 670 & & & \\
\hline Pb5 & & & &, 833 & & \\
\hline Pb3 & & & &, 802 & & \\
\hline Pb4 & & & &, 757 & & \\
\hline Pb6 & & & &, 566 & & \\
\hline Pb2 & & & &, 522 & & \\
\hline Af1 & & & & &, 768 & \\
\hline Af3 & & & & &, 730 & \\
\hline Af2 & & & & &, 729 & \\
\hline G2 & & & & & &, 810 \\
\hline G1 & & & & & &, 781 \\
\hline G3 & & & & & &, 657 \\
\hline
\end{tabular}

Gerçekleştirilen faktör analizi sonucunda ortaya çıkan faktörler için ayrı ayrı yapılan güvenirlik analizinde her bir faktör için Cronbach's alpha $(\alpha)$ güvenirlik katsayısı hesaplanmıştır. Cronbach's alpha $(\alpha)$ güvenirlik katsayısı, testin güvenirliğini belirlemede kullanılan bir teknik olup maddeler arasındaki tutarlılığı test eder ve bu katsayının 0.70 ve üzerinde olması ölçeğin güvenirliğinin iyi olduğunu gösterir (Hair ve ark, 2006). Cronbach's alpha güvenirlik katsayıları 0,93 ile 0,76 arasında değişmekte olup bu değer "Davranışsal Niyet" alt boyutu için 0,93, "Öznel Normlar" alt boyutu için 0,92, "Kullanıma Yönelik Tutum" alt boyutu için 0,84, "Performans Beklentisi" alt boyutu için 0,85, "Algılanan Fayda" alt boyutu için 0,89 ve "Gereksinimler" alt boyutu için 0,76'dır. Ölçeklerin güvenirlik katsayıları 0.70 ve üzerinde olduğu için tüm ölçeklerin güvenirliklerinin iyi olduğu söylenebilir (Hair ve ark, 2006)

\subsection{Yapısal Eşitlik Modeli (YEM)}

Araştırma için önerilen modelin uyumlu olup olmadığını test etmeden önce, toplanan verileri tutarlılık kontrolü için bazı testlerden geçirmek gerekmektedir. Bunlar; faktör yükleri, örtük değişkenler (örn. G, AF, KYT...vb.) arasındaki kovaryans, kompozit güvenirlik (Composite Reliability - CR) ve çıkartılan ortalama varyans (Average Variance Extracted - AVE)'dir. Bu testlerin belirli ölçütleri sağlaması gerekmektedir. Her bir gizil (örtük) değişkene ait standart faktör yükünün 0,50'in üzerinde olması ve bu değerin istatistiksel anlamlı olması gerekmektedir (Fornell ve Larcker, 1981). Her bir yapı için (gizil değişken için) yapı güvenirliği - compozit güvenirlik değerinin 0,70 üzerinde olması gerekmektedir (Hair ve diğ., 2006). Ayrıca, her bir yapı için (gizil değişken için) AVE değerinin 0,50'den yüksek olması gerekmektedir (Leong ve diğ. 2013; Schierz ve diğ. 2010)

Önerilen model, uyum ölçütleri açısından uyumlu değildir. $x^{2}=2589,57-d f=399-x^{2} / S d=6,49-p<0,00-R M S E A=0,12-C F I=0,90-$ $\mathrm{NFI}=0,88-\mathrm{NNFI}(\mathrm{TLI})=0,88$

Kullanıma Yönelik Tutum değişkenine ait bazı maddelerin standart yük değerlerinin düşük olduğu tespit edilmiş $(>0,50)$ (Fornell ve Larcker, 198) ve bu maddelerin yapılacak olan yeni model testinde yer almamasına karar verilmiştir. Bu bağlamda, kyt4, kyt5, kyt7 ve pb3 nolu maddeler, yük değerlerinin düşük olmasından dolayı modelden çıkartılmıştır. Bunun dışında, model çıktısı, modelin iyileştirilmesi ve uyum ölçütleri açısından uyumlu hale gelebilmesi için bazı hata (error) değişkenleri arasında bağ kurulması gerektiğini önermiştir. Hata değişkenleri arasında kurulan bağlar ve çıkartılan 3 madde ile revize edilen model yeniden test edilmiştir. 
Şekil 4: Lisrel Programından Çıkan Revize Edilen Modelin Test Sonucu

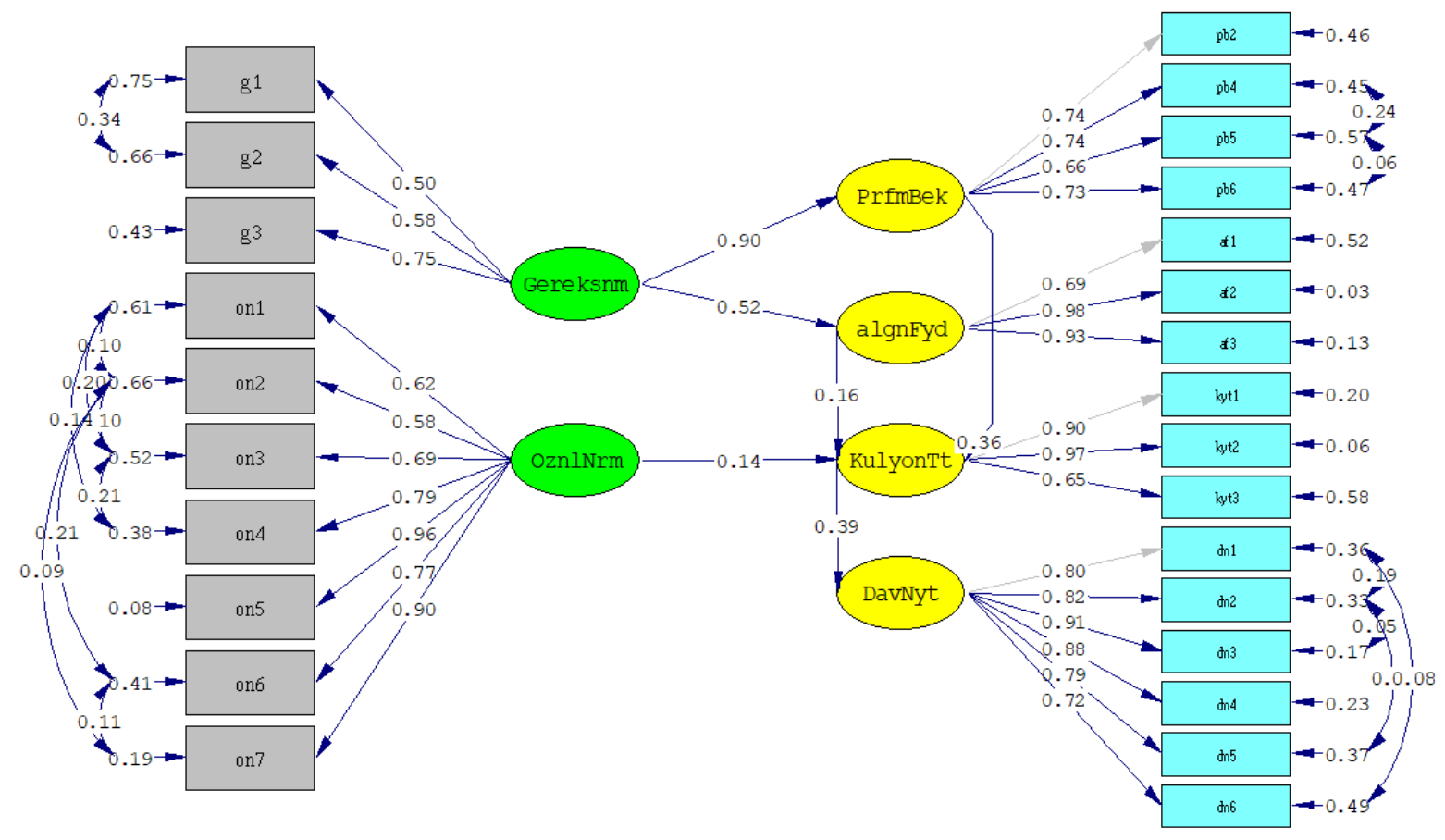

Test edilen revize model ve standart yükler Şekil 4.'de verilmiştir. Revize dilen modele ilişkin uyum indekslerine bakıldığında, revize edilen modelin bu indekslere uyum gösterdiği söylenebilir.

$x^{2}=729,00-d f=277-x^{2} / S d=2,63-p<0,00-R M S E A=0,065-C F I=0,97-N F I=0,95-N N F I(T L I)=0,96$

Tablo 6: Ölçüm Modeline Ait Değerler

\begin{tabular}{|l|c|c|c|}
\hline Uyum Indeksleri & $\begin{array}{c}\text { Mükemmel } \\
\text { Uyum Ölçütleri }\end{array}$ & $\begin{array}{c}\text { Kabul Edilebilir } \\
\text { Uyum Ölçütleri }\end{array}$ & $\begin{array}{c}\text { Ölçülen } \\
\text { Uyum Ölçütleri }\end{array}$ \\
\hline$\chi^{2} / \mathrm{Sd}$ & $0 \leq \chi^{2} / \mathrm{Sd} \leq 2$ & $2 \leq \chi^{2} / \mathrm{Sd} \leq 3$ & 2,63 \\
\hline $\mathrm{RMSEA}$ & $.00 \leq \mathrm{RMSEA} \leq .05$ & $.05 \leq \mathrm{RMSEA} \leq .08$ & 0,065 \\
\hline CFI & $.95 \leq \mathrm{CFI} \leq 1.00$ & $.90 \leq \mathrm{CFI} \leq .95$ & 0,97 \\
\hline NFI & $.95 \leq \mathrm{NFI} \leq 1.00$ & $.90 \leq \mathrm{NFI} \leq .95$ & 0,95 \\
\hline NNFI (TLI) & $.95 \leq \mathrm{NNFI} \leq 1.00$ & $.90 \leq \mathrm{NNFI} \leq .95$ & 0,96 \\
\hline
\end{tabular}

Tablo 7: Araştırma Modeli Için Yapısal Eşitlik Model Sonuçları

\begin{tabular}{|l|l|l|l|l|l|l|}
\hline & Standart Yükler & Tahmin & Standart Hata & T -değeri & p değeri & $\mathbf{R}^{\mathbf{2}}$ \\
\hline Davranışsal Niyet (DN) & & & & & & \\
\hline Dn1 & 0,802 & 1 & 0,010 & & & 0,640 \\
\hline Dn2 & 0,817 & 0,966 & 0,009 & 25,491 & 0,001 & 0,674 \\
\hline Dn3 & 0,912 & 1,221 & 0,008 & 20,860 & 0,001 & 0,833 \\
\hline Dn4 & 0,880 & 1,145 & 0,008 & 19,964 & 0,001 & 0,776 \\
\hline Dn5 & 0,794 & 1,259 & 0,017 & 17,337 & 0,001 & 0,631 \\
\hline Dn6 & 0,717 & 1,062 & 0,019 & 16,784 & 0,001 & 0,510 \\
\hline Öznel Normlar (ÖN) & & & & & & \\
\hline On1 & 0,621 & 1 & 0,059 & 13,139 & & 0,393 \\
\hline On2 & 0,584 & 1,254 & 0,11 & 12,102 & 0,001 & 0,344 \\
\hline On3 & 0,691 & 1,021 & 0,043 & 15,087 & 0,001 & 0,483 \\
\hline On4 & 0,790 & 1,210 & 0,035 & 18,182 & 0,001 & 0,621 \\
\hline On5 & 0,958 & 1,807 & 0,036 & 24,503 & 0,001 & 0,922 \\
\hline
\end{tabular}




\begin{tabular}{|l|l|l|l|l|l|l|}
\hline On6 & 0,769 & 1,597 & 0,072 & 17,296 & 0,001 & 0,594 \\
\hline On7 & 0,902 & 1,808 & 0,044 & 22,167 & 0,001 & 0,810 \\
\hline $\begin{array}{l}\text { Kullanıma Yönelik Tutum } \\
\text { (KYT) }\end{array}$ & & & & & \\
\hline Kyt1 & & & & & \\
\hline Kyt2 & 0,895 & 0,734 & 0,011 & & & 0,801 \\
\hline Kyt3 & 0,971 & 0,840 & 0,012 & 26.034 & 0,001 & 0,940 \\
\hline Performans Beklentisi (PB) & 0,650 & 1 & 0,042 & 14.942 & 0,001 & 0,423 \\
\hline Pb2 & & & & & \\
\hline Pb4 & 0,738 & 1,155 & 0,007 & & 0,001 & 0,543 \\
\hline Pb5 & 0,742 & 1,568 & 0,013 & 12,902 & 0,001 & 0,552 \\
\hline Pb6 & 0,656 & 1,336 & 0,015 & 11,163 & 0,001 & 0,431 \\
\hline Algilanan Fayda (AF) & 0,729 & 1 & 0,005 & 12,707 & 0,001 & 0,532 \\
\hline Af1 & & & & & \\
\hline Af2 & 0,690 & 0,558 & 0,004 & & & 0,484 \\
\hline Af3 & 0,983 & 1,110 & 0,004 & 17,345 & 0,001 & 0,973 \\
\hline Gereksinimler (G) & 0,933 & 1 & 0,003 & 17,187 & 0,001 & 0,872 \\
\hline G1 & & & & & \\
\hline G2 & 0,50 & 1,104 & 0,020 & 9,266 & 0,001 & 0,253 \\
\hline G3 & 0,58 & 1,058 & 0,013 & 11,131 & 0,001 & 0,342 \\
\hline
\end{tabular}

Gizil değişkenleri açıklayan değişkenlere bakıldığında, Davranışsal niyet boyutunu en iyi açıklayan maddelerin "Dn3" nolu madde olduğu; özne normal boyutunu açıklayan en iyi maddenin "On5" nolu madde olduğu; kullanışa yönelik tutum boyutunu açıklayan en iyi maddenin "Kyt2" nolu madde olduğu; performans beklentisi boyutunu açıklayan en iyi maddenin "PB4" nolu madde olduğu; algılanan fayda boyutunu açıklayan en iyi maddenin "Af2" nolu madde olduğu; ve gereksinimler boyutunu açıklayan en iyi maddenin "G3" nolu madde olduğu görülmektedir. Ayrıca, faktör yüklerine bakıldığında, modeldeki tüm maddelerin gizil değişkenlere ait faktörleri açıkladığı anlaşılmaktadır.

Revize edilen modeldeki gizil değişkenlere ait AVE ve CR değerleri Tablo 8'de verilmiştir.

\section{Tablo 2: Gizil Değişkenlere Ait AVE Ve CR Değerleri}

\begin{tabular}{|l|c|c|c|}
\hline Faktör adı & Kısaltma & Ortalama Açıklanan varyans (AVE) & Yapı Güvenirliği (CR) \\
\hline Davranışsal niyet & DN & 0,68 & 0,93 \\
\hline Öznel normlar & ÖN & 0,59 & 0,91 \\
\hline Kullanıma yönelik tutum & KYT & 0,58 & 0,80 \\
\hline Performans beklentisi & PB & 0,52 & 0,81 \\
\hline Algılanan fayda & AF & 0,77 & 0,91 \\
\hline Gereksinimler & G & 0,40 & 0,66 \\
\hline
\end{tabular}

Davranışsal niyet boyutuna ilişkin AVE değeri 0,68, CR değeri 0,93; öznel normal boyutuna ilişkin AVE değeri 0,59, CR değeri 0,91; kullanıma yönelik tutum boyutuna ilişkin AVE değeri 0,58, CR değeri 0,80; performans beklentisi boyutu için AVE değeri 0,52 , CR değeri 0,81; algılanan fayda boyutu için AVE değeri 0,77 , CR değeri 0,91; ve gereksinimler boyutu için AVE değeri 0,40, CR değeri $0,66^{\prime}$ dır.

Gereksinimler boyutu dışındaki tüm boyutların ortalama açıklanan varyans (AVE) ve yapı güvenirliği (CR) değerleri literatürdeki ölçütler açısından uyum göstermektedir. Ancak Gereksinimler boyutundaki AVE değeri 0,50'den (Fornell ve Larcker, 1981) küçük ve CR değeri 0,70'den (Hair ve ark., 2006) küçüktür. Bu değerlerinin küçük olmasının nedeni bu boyutta yer alan maddelere ilişkin faktörler yüklerinin düşük olmasından kaynaklanmaktadır. Her ne kadar bu değerler düşük olsa da 0,50 değerine eşit ve büyüktür (Fornell ve Larcker, 1981) ve kabul edilebilir düzeydedir. Fornell ve Larcker (1981), AVE değerinin 0,50'den düşük olduğu durumlarda CR değerine bakılması gerektiğini ve bu değerin 0,60 olması durumunda boyutun (yapının) yakınsak geçerliğinin hala geçerli olabileceğini ifade etmiştir. Gereksinimler boyutuna ait AVE $(0,40)$ ve CR $(0,66)$ değerleri yukarıda sözü edilen açıklamaya birebir uymakta olup, yakınsak geçerlik açısından uygun olarak kabul edilmiştir.

Amos programında yapılan yapısal eşitlik modelinde ki çıkan sonuçlardan emin olmak için, Amos programından daha güncel olan Lisrel programında da yapısal eşitlik modeli yapılmıştır. Sonuçları aşağıda gösterilmiştir. 
Tablo 9: Yapısal Eşitlik Modelinin Hipotez Test Sonuçları ( $N=382)$

\begin{tabular}{|l|l|l|l|l|l|l|}
\hline Hipotez & $\begin{array}{l}\text { Doğrudan } \\
\text { Etkiler }\end{array}$ & $\begin{array}{l}\text { Standart } \\
\text { Yükler }\end{array}$ & Tahmin & $\begin{array}{l}\text { Standart } \\
\text { Hata }\end{array}$ & $\mathrm{t}$ & Sonuç \\
\hline H1 & G $\rightarrow$ AF & 0,518 & 0,794 & 0,099 & $8,457^{*}$ & Desteklendi \\
\hline H2 & G $\rightarrow$ PB & 0,900 & 0,880 & 0,068 & $12,899^{*}$ & Desteklendi \\
\hline H3 & AF $\rightarrow$ KYT & 0,162 & 0,410 & 0,056 & $2,874^{*}$ & Desteklendi \\
\hline H4 & PB $\rightarrow$ KYT & 0,388 & 0,672 & 0,064 & $5,567^{*}$ & Desteklendi \\
\hline H5 & ÖN $\rightarrow$ KYT & 0,144 & 0,186 & 0,049 & $2,938^{*}$ & Desteklendi \\
\hline H6 & KYT $\rightarrow$ DN & 0,388 & 0,352 & 0,054 & $7,234^{*}$ & Desteklendi \\
\hline
\end{tabular}

$\begin{array}{ll}\text { Algılanan Fayda } & =0,52 * \text { Gereksinimler } \\ \text { Performans Beklentisi } & =0,90 * \text { Gereksinimler } \\ \text { Kullanıma Yönelik Tutum } & =0,16 * \text { Algılanan Fayda }+0,36 * \text { Performans Beklentisi }+0,14 * \text { Öznel Normlar } \\ \text { Davranışsal Niyet } & =0,39 * \text { Kullanıma Yönelik Tutum }\end{array}$

Tablo 9'dan de anlaşılacağı üzere, model üzerinde kurulan tüm hipotezlerin sonuçları istatistiksel olarak anlamlı olup tüm hipotezler desteklenmiştir. Gereksinimler değişkeni algılanan fayda değişkenini 0,52 oranında, performans beklentisi değişkenini ise, 0,90 oranında etkilemektedir. Algılanan fayda değişkeni kullanıma yönelik tutum değişkenini 0,16 oranında etkilemektedir. Performans beklentisi değişkeni algılanan fayda değişkenini 0,36 oranında etkilemektedir. Öznel normal değişkeni kullanıma yönelik tutum değişkenini 0,14 oranında etkilemektedir; Kullanıma yönelik tutum değişkeni ise davranışsal niyet değişkenini 0,39 oranında etkilemektedir.

\section{SONUÇ}

Bu çalışmada mobil bankacılık kullanan müşterilerin gereksinimleri, algılanan fayda, kullanıma yönelik tutumları, performans beklentileri, öznel normlar ve davranışsal niyet değişkenlerine ilişkin görüşleri belirlenmiş ve bu değişkenler arasındaki ilişki analiz edilmiştir.

Araştırma bağlamında katılımcıların ne sıklıkla mobil bankacılık hizmetlerini kullandıkları incelenmiş ve çoğunluğun (\%72) asgari ayda bir defa bu hizmetten faydalandığı gözlenmiştir. Bu bağlamda kayda değer bir katılımcının da bankaya gitme sıklığının yılda bir defaya $(\% 40,3)$ kadar inmiş olduğu gözlenmiştir. Katılımcıların çoğunluğunun mobil bankacılık hizmetlerini 5-6 yıldır kullanmakta olduğu tespit edilmiş, en çok kullanılan mobil bankacılık uygulamasının ise sırasıyla GarantiBBVA Bankası ve Ziraat Bankası olduğu tespit edilmiştir.

Katılımcıların, mobil uygulama kabul modelinde yer alan değişkenlere yönelik görüşlerinin cinsiyetlere bağlı olarak değişmediği gözlenmiştir. Davranışsal niyet, kullanıma yönelik tutum ve öznel normlar boyutlarındaki anket cevaplarına katılmalarının, 40 yaş ve üstü katılımcılarda en az, 26-35 yaş grubunda ise daha yüksek düzeyde olduğu tespit edilmiştir.

Katılımcıların yalnızca kullanıma yönelik tutum boyutundaki anket cevaplarına katılmalarının, eğitim durumları açısından anlamlı bir şekilde farklılaştığı gözlenmiştir. Lisansüstü eğitim düzeyine sahip olan katılımcıların anket cevaplarına katılmalarının, ön lisans eğitim düzeyine sahip olan katılımcıların görüşlerinden daha yüksektir.

Çalışma kapsamında mobil uygulama kabul modelinin alt boyutları arasındaki ilişkiler incelenmiş, bunun sonucunda gereksinimler ile algılanan fayda arasında anlamlı düzeyde ve pozitif yönlü bir ilişkinin varlığı tespit edilmiştir. Buna bağlı olarak gereksinimleri karşılayacak faydaların sağlanmasının mobil bankacılığın benimsenmesine olumlu katkılar sağlayacağı ifade edilebilir.

Mobil uygulama kabul modelinin alt boyutlarından algılanan fayda ile kullanıma yönelik tutum arasında anlamlı düzeyde ve pozitif yönlü bir ilişkinin varlığı tespit edilmiştir. Zira teknolojinin kullanımından sağlanan faydanın kullanıma yönelik tutumu geliştirebileceği değerlendirilebilir. Teknoloji kabul modelinde temel olarak kullanıcıların faydalı gördüğü uygulamaları kullanmaya daha fazla meyil göstereceği ileri sürülmektedir. Sonuç olarak bankaya gitmeden mobil uygulama üzerinden işlerini halleden, bu sayede zaman ve kaynak faydası sağlayan bir kullanıcının kullanıma yönelik tutumlarının da artacağı söylenebilir.

Mobil bankacılık uygulamalarından performans beklentisi ile algılanan fayda arasında anlamlı düzeyde ve pozitif yönlü bir ilişkinin varlığı tespit edilmiştir. Mobil bankacılık uygulamalarının daha pratik, çözüm odaklı, hızlı olması müşterilerin daha fazla fayda sağlayacaklarına yönelik algılarına olumlu etkide bulunacağı değerlendirilmektedir.

Mobil uygulama kabul modelinin alt boyutlarından gereksinimler ile performans beklentisi arasında anlamlı düzeyde ve pozitif yönlü bir ilişkinin varlığı tespit edilmiştir. Mobil bankacılık uygulaması kullanan bir müşterinin, gereksinimlerini karşılayacak bir performans beklemesinin doğal olduğu değerlendirilmektedir. Zira yüksek düzeyde gereksinimleri olan bir müşterinin hızlı, çözüm odaklı, çeşitli hizmetlere çevrimiçi olanak tanıyan, kısaca yüksek performanslı bir uygulamayı talep edeceği değerlendirilmektedir. 
Öznel normların kullanıma yönelik tutum üzerinde pozitif yönde etkiye sahip olduğu görülmüştür. Ancak diğer değişkenlerin etkisine göre nispeten düşük kaldığı da gözlenmiştir. Bu çalışmada da mobil bankacılığın sık kullanılması ve kullanıcıların eğitim düzeyinin yüksek olması nedeniyle, mobil bankacılık kullanımı konusunda sosyal çevrelerinden daha az etkilendikleri değerlendirilmektedir. Katılımcıların mobil bankacılık konusunda kendi becerileri ve araştırma ve ilgi düzeylerinin kullanımlarına yönelik tutumlarını daha çok etkilediğinden dolayı öznel normların etkisinin olumlu da olsa düşük düzeyde olduğu düşünülmektedir. Sonuç olarak sosyal çevrenin mobil bankacılık kullanımına yönelik düşük düzeyde de olsa etkili olduğu ifade edilebilir.

Mobil uygulama kabul modelinin alt boyutlarından kullanıma yönelik tutum ile davranışsal niyet arasında anlamlı düzeyde ve pozitif yönlü bir ilişkinin varlığı tespit edilmiştir. Sonuç olarak mobil bankacılıkla ilgili bireylerin olumlu düşüncelerinin artması halinde kullanma niyetlerinin de artacağı ve bunun da kullanma davranışına olumlu etkileyeceği söylenebilir.

\section{Sektöre Yönelik Öneriler}

Elde edilen sonuçlar dikkate alındığında bankacılık sektörü açısından sunulan mobil uygulamaların benimsenmesinde algılanan fayda, performans, kullanıma yönelik olumlu tutum ve çevrenin etkisinin önemli olduğu gözlenmiştir. Bu kapsamda bankaların;

- Mobil bankacılık hizmetlerini kullanıc dostu olarak tasarlaması,

- Sürekli olarak geliştirmesi,

- $\quad$ Basit, süratli ve güvenilir özelliklere sahip olacak şekilde işletmesi,

- Yapay zeka, nesnelerin interneti, dijital cüzdan, sanal gerçeklik gibi yeniliklerin mobil hizmetlere entegre edilmesi,

- Bu hizmetleri güvenilir platformlarda vermesi,

- Mobil uygulamalarda göz tanıma, yüz tanıma, parmak izi tanıma gibi çeşitli teknolojik güvenlik önlemleri uygulamaları önerilmektedir.

\section{REFERANSLAR}

Akça, Y., Özer, G. (2012). Teknoloji kabul modeli'nin kurumsal kaynak planlaması uygulamalarında kullanılması. Business and Economics Research Journal, 3(2), 79-96.

BDDK, (2020). Türkiye'deki Bankalar, https://www.bddk.org.tr/Kuruluslar-Kategori/Bankalar/1, E.T. 06.05.2020

Çokluk, Ö., Şekercioğlu, G., Büyüköztürk, Ş. (2012). Sosyal bilimler için çok değişkenli istatistik: SPSS ve lisrel uygulamaları. Pegem Akademi Yayıncılık, Ankara.

Davis F.D., (1989). Perceived usefulness perceived ease of use, and user acceptance of information technology. MIS Quarterly, 13 (3), $319-340$.

Doğan, E. (2012). Banka ve Bankacılık Kavramları. (Ed. F. Kaya), Bankacılık Giriş ve İlkeleri. İstanbul: Beta Yayıncılık.

Eren, A., Kaya, M. D., (2017). Üniversite öğrencilerinin uzaktan eğitim sistemine bakış açılarının teknoloji kabul modeli ile incelenmesi. Yüzüncü Yıl Üniversitesi Sosyal Bilimler Enstitüsü Dergisi, 35, 203-222.

Fornell C., Larcker D. F. (1981). Evaluating structural equation models with unobservable variables and measurement error. Journal of Marketing Research, 18(1), 39-50.

Gambhir, P., Bevan, P. and Devemport, F. (2018). Unlocking supply chain benefits through blockchain Technology. Blockchain accelerates insurance transformation, KPMG, Canada.

Gjino, G., Findiku, O. I. (2014). Mobile banking - near future of banking. Review of Applied Socio- Economic Research, 7(1), $43-51$.

Göğüş, Ç. Ç. (2014). Teknoloji Kabul Modeli ve Değiştirme Maliyetinin Müşteri Sadakati Üzerine Etkileri: Muhasebe Yazılım Programları Üzerine Bir Çalışma, Yayımlanmamış Doktora Tezi, T.C. Gebze Yüksek Teknoloji Enstitüsü Sosyal Bilimler Enstitüsü, Kocaeli.

Gürbüz, S., Şahin, F. (2016). Sosyal Bilimlerde Araştırma Yöntemleri: Felsefe, Yöntem ve Analiz (3. Basım). Ankara: Seçkin Yayınları.

Gürses, F. (2016). Türkiye'de Yerel Yönetimlerde Yöneticiler ve Vatandaşlar Perspektifinden E-Devlet'in Benimsenmesi: Bursa Büyükşehir Belediyesi Örneği, Yayımlanmamış Doktora Tezi, Uludağ Üniversitesi Sosyal Bilimler Enstitüsü, Bursa.

Güven, Ö. F., Öztürk, A. (2014). Bankacılık ve Sigortacılıkta Pazarlama, İstanbul: Beta Basım A.Ş.

Hair, J.F., Black, W.C., Babin, B.J., Anderson, R.E., Tatham, R.L. (2006). Multivariate data analysis (8th ed.). New Jersey: Pearson Prentice Hall. 
Leong, L. Y., Hew, T. S., Tan, G. W. H. , Ooi, K. B. (2013). Predicting the determinants of NFC enabled mobile credit card acceptance: A neural network approach. Expert Systems with Application 40, 5604 - 5620.

Özer, L., Kement, Ü., Gültekin, B. (2015). Genişletilmiş Planlanmış Davranış Teorisi Kapsamında Yeşil Yıldızlı Otelleri Tekrar Ziyaret Etme Niyeti, Hacettepe Üniversitesi IiBF Dergisi, 33(4), 59-85.

Özkan, T., İpekten, O. B. (2017). İnternet Bankacılı̆̆ı Kullanımını Etkileyen Faktörler: Atatürk Üniversitesi Personeli Üzerine Bir Uygulama, Atatürk Üniversitesi Sosyal Bilimler Enstitüsü Dergisi, 21 (2), 647-664.

Paçan Özcan, H., Sabah Çelik, Ş., Özer, A. (2019). Bireysel müşterilerin mobil bankacılık kullanım niyetini etkileyen faktörler. Çankırı Karatekin Üniversitesi iiBß Dergisi, 9(2), 475-506.

Schierz, P. G., Schilke, O., Wirtz, B. W. (2010). Understanding consumer acceptance of mobile payment services: An empirical analysis. Electronic Commerce Research and Applications 9, $209-216$.

Serçemeli, M. ve Kurnaz, E. (2016). Denetimde Bilgi Teknoloji Ürünleri Kullanımının Teknoloji Kabul Modeli (TKM) İle Araştırılması, İstanbul Üniversitesi İ̧̧letme Fakültesi Dergisi, 45(1), 43-52.

TBB, (2020b). Dijital, Internet ve Mobil Bankacilık İstatistikleri Mart 2020, https://www.tbb.org.tr/Content/Upload/istatistikiraporlar/ekler/1289/Dijital-Internet-Mobil_Bankacilik Istatistikleri-Mart_2020.pdf, E.T. 06.05.2020

Uğur, N. G.,Turan, A. H., (2016). Mobil uygulama kabul modeli: bir ölçek geliştirme çalışması. Hacettepe Üniversitesi iỉBF Dergisi, 34 (4), $97-126$.

Yıldırır, S. C., Kaplan, B., (2019). Mobil uygulama kullanımının benimsenmesi: teknoloji kabul modeli ile bir çalışma. Kafkas Üniversitesi iïBF Dergisi, 10(19), 22-51.

Yılmaz, M. B., Kavanoz, S., (2017). Teknoloji kabul ve kullanım birleştirilmiş modeli-2 ölçeğinin türkçe formunun geçerlik ve güvenirlik çalışması. International Periodical for the Languages, Literature and History of Turkish or Turkic, 12(32), 127-146. 